\title{
Children's perceptions of their right to quality healthcare in Uganda: Critical gaps in programme and policy development
}

\begin{abstract}
Author:
Hilda K. Nankunda ${ }^{1}$

Affiliation:

${ }^{1}$ School of Social Work, University of Central

Lancashire, United Kingdom

Correspondence to:

Hilda Nankunda

Email:

hildananku@yahoo.co.uk

Postal address:

84 Raglan Street, Ashton on Ribble, PR2 2AX Preston,

Lancashire, United Kingdom

Dates:

Received: 11 May 2015

Accepted: 14 Sept. 2015

Published: 12 Oct. 2015

How to cite this article:

Nankunda, H.K., 2015,

'Children's perceptions of their right to quality healthcare in Uganda: Critical gaps in programme and policy development', African Evaluation Journal 3(2), Art. \#155, 9 pages. http://dx.doi. org/10.4102/aej.v3i2.155
\end{abstract}

\section{Copyright:}

(C) 2014. The Authors.

Licensee: AOSIS

OpenJournals. This work is licensed under the Creative Commons Attribution License.
Scan this $Q R$ code with your smart phone or mobile device to read online.
Read online:

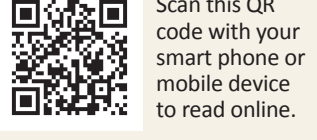

In 1989, Article 24 of the Convention on the Rights of the Child (UNCRC) stipulated good quality healthcare, the best healthcare possible, as a human right for every child. This qualitative study in Uganda examined children's awareness of and access to timely, quality healthcare as part of a broader study examining whether institutions established for children in Africa are raising awareness about children's rights amongst children and engaging with children in decision-making and planning. To establish whether children possessed knowledge of their rights and could inform decisions at a community level. Using action research approaches, the team conducted focus group discussions (FGD), drawing, key informant interviews (KII), dialogue meetings (DM), and observations in one village in a rural and another in a peri-urban district, with 72 participants (21 children aged 10-15 and 51 adult stakeholders at community, district and national levels). Children were aware of their right to quality health services. In FGDs and drawing, children described their dissatisfaction with and difficulties in accessing healthcare services. These were confirmed with the adult stakeholders in the KIIs and DMs, the DMs also including children who presented their FGD results to community stakeholders. The findings suggested a lack of clear guidelines in schools or health facilities to support children needing medical attention. There was limited stakeholder capacity to involve children meaningfully in programme plans and decisions directly affecting them. Recommendations included the development of explicit policies with specific strong linkages between educational, health and other service institutions to promote, protect and respect children's rights and also training to elicit children's perspectives in decisions that affect them.

\section{Introduction}

Article 24 of the Convention on the Rights of the Child (UNCRC), 1998 stipulates good quality healthcare, the best healthcare possible, as a human right for every child. Signatory nations to the UNCRC endeavour to ensure that every child enjoys human rights wherever they live. Some government institutions, Civil Society Organisations (CSO), and others work to ensure the realisation of the human rights of children $0-17$ years. Governmental health-related policies and programmes for children are also implemented directly through interventions in the lives of children and indirectly through relevant services in the communities. Nevertheless, after 25 years of the UNCRC, children's rights remain unfulfilled for most children living in Africa (Muzaki 2011; UNICEF 2009; UNICEF 2013a; 2013b; United Nations, CRC/C/SR.1370 2009). The Committee on the Rights of the Child noted the suffering endured by children in many countries, including the Democratic Republic of the Congo, Uganda and Sierra Leone due to conflict (United Nations, CRC/C/SR.1370 2009). The Millennium Development Goals (MDGs) reports reveal that most children do not have access to health services and their health situation is still poor (Government of Uganda [GOU] 2013).

\section{Background}

Africa remains a region in which large numbers of children continue to die of preventable causes. The persistence of preventable deaths, child hunger and malnutrition, lack of access to health care services, low school completion rates, and declining educational quality in the region continue to prove obstacles for improving children's well-being (Government of Uganda [GOU] 2013 b; Government of Uganda [GOU] 2012). The UNICEF report observed that every disadvantaged child bears witness to a moral offense by the state's failure to secure her or his rights to survive, thrive and participate in society (UNICEF 2012; 2013a). This is true for most children in African countries. Uganda, for instance, was ranked the 19 th highest country globally for under- 5 deaths, mainly caused by malaria, diarrhoea and pneumonia. Malnutrition rates for the under- 5 were also high, at $38 \%$. Poor sanitation coupled with unsafe water sources also contributed to the disease 
burden, including dysentery, diarrhoea and typhoid fever (WHO 2011). Uganda adopted the UNCRC 1989 and revised the Constitution to reflect its provisions. In fact, Article 34, clauses 1-7 of the Uganda Constitution (1995) spells out the rights of children, including clauses 3 and 4, which mention the right to medical treatment and health for children.

The report from the Uganda national validation workshop that the National Council for Children (NCC) conducted (2010) documented the reality that parents were not aware of children's right to participate, and they were also not empowered to support children to participate in activities that affect them. The workshop further revealed that children did not participate in Child Protection Committees where they existed. At village level, the Secretaries for Children position on the Local Council I (LC.I) which is responsible for child protection did not acknowledge children's participation as being beneficial to the success of the projects. Children were left out of most of the council activities, including those related to child protection. The local government structure has not provided for child participation in community activities other than children's responsibilities in the family (NCC 2010). This evidence demonstrated the inadequate capacity of children, adults and other stakeholders to implement the UNCRC and the general lack of awareness of children's rights. Children, caregivers and communities also lacked an awareness of what constitutes abuse and criminal offences against children. These have caused persistent insecurity for children and have been an impediment to child protection efforts as most of the abuses have remained unreported. Furthermore, orphans and vulnerable children (OVC) are not even aware of their rights, so the rights violations in that specific child population persist (Government of Uganda [GOU] 2009, SITAN).

This article describes a study of children's access to healthcare services and rights conducted in two districts in Uganda. The study had four objectives:

- To reveal whether Ugandan children are aware of their human rights.

- To identify ways through which government institutions have engaged and are able to engage with children to promote an awareness of children's rights amongst children and ways to report and rectify abuses and violations.

- To determine avenues through which children can be involved in realising their rights across existing government structures.

- To explore ways of encouraging children's rights' stakeholders (children, parents, communities, nongovernmental organisations (NGO), central government) in order to respond to children's rights issues and to involve children in planning and decision-making about issues and programmes critical to them.

\section{Literature review}

This review describes the literature related to children's rights and children's perspectives.

\section{Children's rights}

Many authors (Archard 1993; Freeman 1997; 2000; Hale 2006; Thomas 2002; UNICEF 2003) agree that the rights of the child are those basic human rights or entitlements such as the right to survive and to have basic needs met; to health; to develop and reach their fullest potential; to be protected from harm, exploitation and abuse; and to participate.

By virtue of having human rights, therefore, children are entitled to be actively involved in those decisions which affect them as individuals in the family, in schools, in public care, in the courts and as a participant in the development, delivery, monitoring and evaluation of public policy at both local and national levels. Lansdown (2001) noted that children who experience respect for their views and are encouraged to take responsibility for those decisions are competent to make decisions and may acquire the confidence to challenge any abuse of their rights. Wall (2012) observed that children have contributed to positive changes in educational policies, have identified and reported poor teachers, and have improved community services. Unfortunately, these authors are describing isolated cases in which adults invested time and effort to enable children to influence events.

Children's understandings about their human rights are strongly correlated to environmental factors of socioeconomic development and cultural systems (Bronfenbrenner 1986 cited in Bettby, Strang \& Wessells 2006). For example, children in Zimbabwe are described as valuing the right to education as a priority (Gwirayi \& Shumba 2011) but are not aware of other rights as enshrined in the UNCRC. Comparatively speaking, children in Wales speak about their rights to health and well-being; to education; to voicing their opinions and being heard; to freedom, respect and protection from harm and abuse; and to play, have fun and have friends (Thomas, Gran \& Hanson 2010). Differences between these groups may be explained by factors such as exposure to information about their rights, the opportunity to live violence-free and healthy lives, and the level of the country's development.

\section{Children's perspectives}

Children have unique perspectives which in the past have often been ignored. Casas et al. (2006) stress the importance of understanding children's perspectives to be able to include them in decisions that affect them and promote their social participation. The silencing of the voices of children came about because they were considered to lack competence and experience. Their world views and perspectives were thought to be merely a reflection of their parents' or teachers' thinking. Several researchers (Daiute 2008; Moosa-Mitha 2005; Smith 2007) have demonstrated, instead, that children have points of view or ideas that differ from those of their parents, who may never have considered them important.

Children of any age have a sense of reasoning and interpreting as observed in their asking questions about situations in their environment. Adults can influence children's ideas by 
answering the questions they raise. The fact that children are inquisitive means that they have competence and important personal viewpoints (Hanson \& Nieuwenhuys 2013). Smith (2007) suggested that listening to children does not mean doing everything they ask for or giving children's views more weight than those of adults. Rather, it means more respectful listening and taking into account children's perspectives, which is empowering to them. Fortin (2006) cautions that treating children as equal participants could be dangerous as it might foist upon them responsibilities that are beyond their capacities, which can lead to abuse and exposure to danger. Decisions about career and other life issues that can have long-term benefits should be influenced by adults because children may not readily fully appreciate them (Freeman 1983). Children's capacity to be autonomous should be respected. They should be shown due regard by protecting them from 'irrational acts' whilst granting them rights of autonomy when they show the capacity to make independent choices regarding appropriate life situations. To respect a child's autonomy is to treat that child as a person and as a rights-holder (Freeman 1983).

\section{Engaging children}

The literature shows that African countries have not fully embraced the responsibility of engaging children in issues that affect their lives in communities and at other levels. In Madagascar, children's views are sought on special occasions, especially on Child and Youth Day celebrations. Children's Parliaments were reported to exist in Rwanda, Nigeria, and South Africa as means of involving young people in development discussions. However, these activities are irregular and children's issues are not taken seriously (United Nations, CRC/C/15/add.122 2000; United Nations, CRC/C/NIG/4 2010; United Nations, CRC/C/RWA/34 2012). Muzaki (2011) used the child-to-child approach to promoting urban health, which recognised children's potential to link learning with action to promote health, well-being and development in a bigger context of their families, schools and communities. Muzaki further asserted that children, by nature, have a high level of honesty and can effectively pass on messages as they receive and understand them, suggesting that this constitutes an empowering process in the lives of children. The lack of such experiences in many countries further confirms that involving children in decisions that affect them is a critical gap that needs to be addressed by stakeholders in developmental processes.

\section{Research method and design}

This qualitative study conducted in Uganda was a sub-study of a broader study about the application of the 1989 UNCRC. ${ }^{1}$ Action research was selected as the best approach because of its capacity to foster change as an integral part of the research process. MacNiff (2002) describes action research as a process of helping other people to think for themselves and to realise

1.The broader study, The role of independent human rights institutions for children in Africa in raising awareness about children's rights amongst children, examined whether institutions established for children in Africa are raising awareness about whether institutions established for children in Africa are raising awareness about
children's rights among children and engaging with children in decision- making and children's rights among
planning processes. their humanity in doing so. People are better able to speak for themselves in a reflective process. This study applied the six key principles of action research: reflexive critique; dialectical critique; collaborative resources; risk; plural structures; theory, practice and transformation (MacNiff 2002; Winter 1989). We used these approaches to influence opinions about (1) the possibility of eliciting information from children about their rights and (2) engaging parents and children in a dialogue about children's rights in the community.

\section{Setting}

The research was conducted with children in a peri-urban and a 'deep rural' community very far from the capital city. In Wakiso District (central region), the field study was conducted in Nabaziza village (Nsangi sub-county, Kyengera parish), $13 \mathrm{~km}$ from Kampala city. In Rukungiri District (Western Uganda), about $400 \mathrm{~km}$ from the Kampala, study participants were selected from Kanombe village (Buyanja sub-county, Nyabiteete parish).

\section{Design}

The study was a qualitative design, applying a phenomenological field research design (Groenewald 2004; Lester 1999). Epistemologically, phenomenological approaches are based on a paradigm of personal knowledge and subjectivity to emphasise the importance of personal perspectives, reflection and interpretation. The researchers elicited deeper understandings of children's perspectives and explored their experiences with children's rights both at home and in their communities. Qualitative methods used in the study included focus group discussions (FGD), key informant interviews (KII), and dialogue meetings (DM). In addition, drawing, resource mapping and observation were engaged in for non-verbal responses during group activities and meetings.

Data were collected from individual children for sensitive issues such as rights violation and abuse at home and things they do not like at home. Data was collected in groups for other issues such as what they like and do not like about church, the health centre and school. In groups, children reflected on and elaborated upon the responses that were elicited in the individual interviews (Herr 2005).

\section{Procedure Data collection}

Data were collected from children ages 10-15 in group discussions which were conducted in teams of two or five children, guided drawing activities and FGDs. In addition, key stakeholder groups (parents or guardians, community leaders and sub-county, district- and national-level stakeholders) also contributed data. Each stage of the data collection reflected the information the children generated through group activities. Children's experiences of rights realisation and violations at home and in their communities informed discussions held with parents or guardians and 
TABLE 1: Distribution of study participants.

\begin{tabular}{|c|c|c|c|c|c|}
\hline District & Children $10-15$ years & Community dialogue & Sub- county & District & National level \\
\hline Wakiso-Nsangi-Kyengera-Nabaziza & 8 (4 male) & 12 (5 male) & 2 (1 male) & 3 ( 2 male) & \multirow{2}{*}{17 (7 male) } \\
\hline Rukungiri-Buyanja-Nyabiteete-Kanombe & 13 (7 male) & 13 (5 male) & 1 (0 male) & 3 (2 male) & \\
\hline Total & 21 & 25 & 3 & 6 & 17 \\
\hline
\end{tabular}

other community leaders. Children volunteered to present their perceptions of rights to the DMs, reading from the flipcharts pinned on the walls in meeting rooms.

Key informants included probation officers, community development officers at sub-county and district levels, ministry officials at national level and members of CSO. They were interviewed using KII guides. Interviews with these officials provided opportunities to share the perceptions of children about their rights, to seek clarification on the situation observed at a community level, and also to elicit recommendations and policy suggestions as to how to raise awareness successfully about children's rights amongst children. Some KII participants shared their reports and other primary sources on children's rights in the country.

Data were collected during two visits to Nabaziza community and Kanombe village in the period July-December, 2013 and again in March 2014. During the first two weeks of October, data were collected from Nabaziza community; during the last week of October and the first two weeks of November data collection was done in Kanombe. KIIs were also conducted during this time whilst observing for any negative reactions that could affect children as a result of their participation in the research. The first visit during the months of July, August and September covered planning activities with leaders at national and community levels, introduction to the communities, and mobilisation for participation in the action research. The second visit, which was aimed at finding out whether communities had learnt anything from the research to improve the situation of children, revealed that communities were interested in extending discussions about children's rights as part of their local council ${ }^{2}$ meetings.

The principal investigator was fluent in the local languages of both communities and conducted all the discussions or interviews in those languages. The research team also included one NCC stakeholder staff member as a national partner in Nabaziza, and the sub-county community development officer in another village, Kanombe, as district partner. The two officers assisted with note taking during the discussions. They were purposely involved to gain first-hand experience of the process of involving and learning from children.

\section{Study population}

The study included 21 children aged 10-15 in the two communities of Nabaziza and Kanombe as the main

2.Local Council (LC) is the lowest administrative level in every village. An LC comprises about 10 households. The structure goes up to district level, where we have the LC.V chairman. participants, with a total of 72 participants, as shown in Table 1.

Participant selection was purposive in order to identify and involve children in the places where they lived. The children were on school holidays at the time of the study. All the children were in primary school, except for two children in secondary school in their first year, Senior One. ${ }^{3}$

Parents, guardians and community leaders $(n=25)$ who attended the DMs comprised another important participant category that discussed and validated child rights issues in the community. Other key players, such as staff from the Directorate of Social Services responsible for children's issues in the district $(n=9)$, helped to confirm issues from the children's and community meetings as well as share information on children's rights awareness. Children's rights stakeholders at the national level $(n=17)$ were also interviewed.

\section{Ethical considerations}

Transparency was a hallmark of the study from preparation stage to the end of the research process. The research proposal was shared with local partners in the Ministry for Gender Labour and Social Development (MGLSD) and the NCC as local partners in the study. The participation of children and other stakeholders was voluntary. The children were informed that they could opt out of any activity for any reason and at any time. Informed consent was obtained through the community leaders, the LC chairmen. They also mobilised the participants and identified neutral secure venues for the meetings in the community to ensure privacy and confidentiality. To maintain confidentiality, only the principal investigator retained the names and identifying information of the participants, and did so in a secure and locked location.

Ethical approval was obtained from the University of Central Lancashire (UCLan) Research Ethics Committee for the usual ethical requirements for UCLan researchers: to observe the conditions for child protection, consent, access to the participants, ruling out biological concerns related to researching with human subjects concerns mainly. Other issues that may affect the quality of the data and the safety of the researcher during field research, especially when children are involved, were also the subject of ethical approval. 


\section{Analyses}

Data analysis started in the field. As key participants, the children influenced the research process as key participants. Their ideas and perspectives shaped the questions that were asked after every activity and generated the information and instructions for other activities. Different drawings from the groups showing community facilities known to children stimulated the group to discuss children's rights. The drawings depicted the children's awareness of their environment and the useful resources in it.

\section{Discussion}

This study identified many aspects of children's awareness of their rights and of their lack of access to basic rights such as education, health, employment, and freedom from abuse and violence. However, this article focuses specifically on the relationship between health, education and children's access to healthcare as a human right and the effect of household poverty on the realisation of children's rights.

\section{Understanding children's rights}

Information from the drawing and writing activities and the FGDs with children suggests that children's awareness of rights relates to their desired basic needs and service facilities in their communities. Guiding FGD questions assumed that the fulfilment of rights would promote happiness, comfort, and better lives for children in the community (UNICEF 2013b). Children revealed what they did not like in the communities and what made them unhappy or uncomfortable at home. They knew some of their rights as presented in the UNCRC because these are taught in schools as part of the non-examinable curriculum:

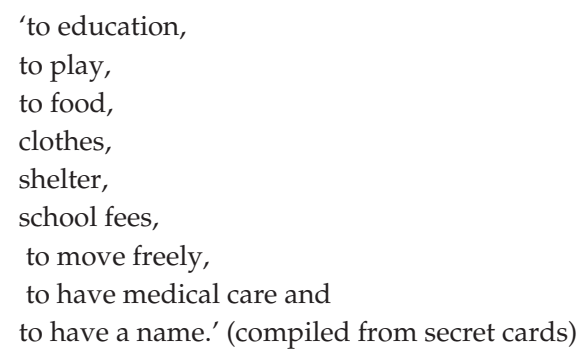

The children mentioned them spontaneously. They also understood their responsibilities regarding their involvement in family chores. However, they did not seem to understand the significance of their rights and how to claim and access them to make their lives happier and more comfortable. Nor did the children have the agency to secure their rights.

\section{Children's perceptions of health-seeking practices and health facility personnel}

The children discussed the right to health (Article 24, UNCRC). Health facilities in Nabaziza and Kanombe include government health centres, private clinics and drug shops (pharmacies). However, the children wanted good health centres and more hospitals to guarantee their right to access to healthcare, and therefore to health. They also voiced their concerns about the quality of the services at healthcare facilities that they expected in terms of structure, equipment and staff:

'... there should be personnel to provide services in these facilities.' (Child 4a, 10 years old)

'... nurses and doctors treat you when you are sick.' (Child 1a, 11 years old)

Children in both of the villages reported that the existing health facilities were of poor quality and there seemed to be a shortage of well-trained personnel. The children emphatically stated what they wanted:

'... good health centres with well-trained doctors ... sometimes when they give you medicine you do not improve / get better ...' (Child 8b, 12 years old)

'... they give only panadol [pain killers] sometimes they give you medicine and you do not get cured ... some doctors are not trained.' (Child 6a, 11 years old)

The children also commented on the nature of the drugs administered:

'... the medicine is duplicated ...' (Child $8 b, 12$ years old)

This may have been heard as a complaint from their parents. They mentioned common children's illnesses in the community as being:

'malaria, diarrhoea, kwashiorkor, typhoid and mumps ...' (Child

7a, 10 years old; Child 3a, 12 years old and Child $1 \mathrm{a}, 11$ years old)

The traditional management of illnesses is influenced by superstitious beliefs and the use of local herbs for both the prevention and the treatment of some ailments, including malaria, when some children are sick. The children revealed that local herbal medicine is still used in the treatment of malaria:

'... when the illness worsens, that is when they take you to the clinic or health centres.' (Child $1 b, 10$ years old)

Children make up the majority of deaths from malaria ${ }^{4}$ (New Vision March 2015). Mumps is also locally managed without consulting medical professionals. For example, in Nabaziza, one boy had a thread tied around his neck. He explained its purpose:

'... so that you do not contract the ailment ...' (Child 8a, 10 years old)

He recounted that his neighbours had mumps, so his mother tied it around him to protect him from contracting the disease. The other children were not surprised by this preventive measure.

Although the school health programmes that cover environmental health and sanitation are well supported, it is unclear as to which staff at which service facility are

4.At least 584000 people mostly children in sub-Saharan Africa were estimated to have died of malaria in 2013. 
responsible for the physical health of individual children. The children in Kanombe village also shared their experiences at their health centre, where there are nurses:
'... The nurses are kind. ... they give us medicine.' (Child 5b, 9 years)
'We get medicines and we are treated ... we will get employment after education. ${ }^{5}$ (Child $6 \mathrm{~b}, 11$ years)
'... health education ... we get cured after taking medicines/ drugs.' (Child 10b, 12 years)

The children's claims require further investigation, since they might be related to incorrect dosages or out-of-date drugs. Resistance to certain drugs due to overuse cannot be ruled out either. The state of government health facilities, poor health status of the populations related to poor sanitation, poor hygiene conditions, a high prevalence of disease and a shortage of medicines in health centres are major challenges (Daily Monitor 2014a; Uganda Local Government 2011). Pictorially, children presented a good hospital as a multi-storied building with a road and electric power-line connected from the roof.

\section{Children's perceptions of and experiences with health services}

The children in Nabaziza and Kanombe villages raised pertinent claims about the quality of health services available to them as children in the community. They also shared their impressions about service providers. These were supported by media reports (Daily Monitor 2014b). The children also seemed to doubt the qualifications of some medical personnel and their capacity to make correct diagnoses, especially when illnesses persist. Health services are poor and most people, including children, do not receive specialised, timely care, given the doctor-patient ratio of 1:15 000 (Uganda Bureau of Statistics (UBOS) 2012). Children in Kanombe reported the following negative aspects of health centres:

'when you do not find drugs ... health workers sell drugs, health workers refuse to give drugs to children. They ask children first to bring parents, for instance, when you are at school you fall sick and they send you to the health centre, going to health facility and workers are absent, a child requesting drugs and they say there are no drugs.' (Child 1b, 12 years old; Child 6b, 11 years old)

'... health workers are sometimes rude. For instance, when you have a wound some will say ... "I can't touch this pus" and refuse to dress your wound.' (Child $4 \mathrm{~b}, 11$ years old; Child $1 \mathrm{~b}$, 10 years old)

'... visiting the health centre and health workers say you are not sick ...' (Child $10 \mathrm{~b}, 12$ years old)

\section{Children's perceptions about getting access to services}

All the children in the two villages said that they were immunised - this could be attributed to reported government progress in immunisation, water and sanitation infrastructure (World Bank 2013 report on MDG).

5.Some of the children said they aspired to join the health profession after thei education.
Children shared information about the lives of fellow children and their own lives at schools, at home and in their communities. They reported a lack of clarity about who takes responsibility when a child falls sick whilst at school. Children reported that they were sent unaccompanied from school to the health centres; health centre staff then sent them home to their parents or guardians before they would treat them. This could be due to insufficient co-ordination between schools, health facilities and families; health costs could also be an issue. It raises a concern about both a public policy and a procedural issue associated with linkages between education institutions, health services and family services for children.

In sum, the discussion about the health services in Uganda from the perspective of children in Nabaziza and Kanombe is based on specific experiences and situations in their communities. Secondary sources confirm the children's claims and their need for access to quality health services. In this study, the relationship between their ability to obtain healthcare services and the level of education of these children was not studied.

\section{Children's perceptions of rights violations and abuses}

The children in Kanombe and Nabaziza shared their perceptions of rights violations and abuses. Their description of unfulfilled rights during the FGDs can be summarised in terms of 'excesses' and 'deficiencies' in services and facilities, in their homes and in their communities. These perceptions were corroborated during observations and activities with the children, who stated that:

'... when you are many children in the family; then they tell you to do all the work alone.' (Child 4a, 10 years old)

'... you do all the work at home; when you complain, they threaten to beat or they beat you ...' (Child 4a, 10 years old)

The children reported that they had seen abuse towards orphans in the form of corporal punishment and discrimination within the family. Although Uganda has legislated against corporal punishment, the children's discussions suggested that beating (corporal punishment) by parents translates into a violation of children's rights when it is severe:
'... it is okay to be beaten when we have violated family or school norms.' (Child 1a, 11years old)
'... don't beat us baldly ... beating all over the body ...' (Child $7 \mathrm{a}, 10$ years old)
'... lie down and beat on buttocks ...' (Child 4a, 10 years old)

Discriminating or unequal treatment or sharing within the family ('favouritism') may arise from a scarcity of or inadequate resources or from cultural practices. For example, orphaned children living with guardians feel they are mistreated because they are given more chores and household work than the biological children in the household. These abuses and violations were denied by parents and 
guardians in discussions in Nabaziza. However, in Kanombe community members cited some families where children's rights have been violated. It appears that guardians may lack the skills to effectively and fairly manage their households with children from different families. Guardians may also face constraints and resource challenges unknown to the children that may affect their ability to be fair and equal towards all the children.

The children were aware, however, of family resource constraints associated with schooling and household welfare. Individual activities with the children generated descriptive terms such as:
'not enough money to pay for school fees'
'not enough food and drink'
'not enough accommodation ... space for sleep'
'not enough land to adequately support the household for subsistence and residential house with separate rooms for boys and girls.' (Compiled from secret cards)

Some children drop out of school due to the failure of parents to pay school fees and meet other demands, even when Uganda recorded a $110 \%$ primary school gross enrolment rate (World Bank 2013).

\section{Involving children in decisions that affect them}

The study findings showed that children's issues do not involve children during their planning and implementation processes. The level of child participation is limited to 'manipulation', 'decoration', and 'tokenism', which are steps 1-3 of the participation ladder (Hart 1992). In Uganda, children are not represented on village committees (NCC 2010). It appears that advocates of children's rights do not have the skills to involve children meaningfully in decisionmaking and other activities.

\section{Results from using action research}

Our research illustrated that it is possible to engage with children in community discussions that contribute to planning and policy. The positive response from parents, guardians, community members and community leaders at the dialogue meetings (DM) also promises better promotion, protection and realisation of children's rights. We provided preliminary study findings to the study communities. During the second visit, I found that the Kanombe and Nabaziza communities had held village or LC.I meetings and discussed the research with children as an agenda item for the record. The evaluation responses from the children, observation of the research process and the second visit discussion with some community members revealed that the process was empowering for both the children and the community as the first opportunity for the two communities to participate in research on children's rights. The dialogue on children's rights facilitated by the children was the first ever to occur in the study communities. Local leaders revealed that they had never held any meeting to discuss children's rights prior to our research. Representatives of community members at the DM reported that they greatly appreciated meeting with the children to discuss community issues.

\section{Practical implications}

In this study action research led to discussions to improve practice, better understand practice in regard to implementation of the UNCRC, and to improve children's awareness of their rights. It also led to their revealing their experiences in accessing basic services that promote rights in the community as suggested in Robson (2002).

Action research with children and community members in two villages in Uganda demonstrated that children possess good information that can inform policy and programme activities. Therefore, stakeholders must decide on how best to involve children and bring their perspectives into programming and policy decisions.

Action research enables learning from below or 'bottomup' rather than the 'top-down' approaches that are usually used in development work (Sabatier 1986). This was demonstrated in this study and should be replicated in planning community interventions by stakeholders elsewhere.

At the DMs, the adult audience listened to the children's presentations and then discussed the findings. This demonstrated that learning together as a community to arrive at solutions was possible (similar to the child reporters' project in Orissa [Acharya 2010]).

Staff implementing other development projects may also lack information about children's capacities to identify community problems and even contribute to possible solutions (KII, NCC KII, CFPU KII, ANPPCAN KII). They should therefore be trained in this methodology.

\section{Limitations of the study}

This study was implemented in only two villages in Uganda and participants were selected purposively; the findings must therefore be interpreted with caution. There were also challenges in arranging meetings with nationallevel stakeholders due to their schedules and not everyone contacted was available for an in-depth interview. Some of the children's responses about their health centre experiences may have been unreliable.

\section{Recommendations}

This study established that recognising children's perspectives may contribute to the effectiveness and sustainability of good practices and changes in behaviour, as is the case when the marginalised poor and hard-to-reach are involved in development programmes (Chambers 1997; Chambers \& Conway 1991; Herr 2005). 
The following recommendations are accordingly derived from the study findings: Development workers should bear in mind children's right to participate in decisions that affect them (Article 12, UNCRC 1989). They should accordingly recognise the institutions and structures that are close to children and build their capacity for engaging with children in support of their involvement in planning and policy development. Ugandan stakeholders for children's rights should continue to work towards meaningfully involving children in planning and policy development processes in fulfilment of Article 12 of the UNCRC (1989).

Children 0-17 years old comprise the majority of the population in Uganda and in other African countries. Their need for quality health services and their role in supporting healthy lives is critical. Policy development processes need to be more specific regarding the availability of and access to good quality healthcare for each specific age group of children, in fulfilment of Article 24 of the UNCRC (1989).

Capacity building sessions should be held with stakeholders about how best to elicit the perspectives of children and how to involve them in improving health and human services.

\section{Conclusion}

This study was a successful learning process for children's rights stakeholders. It demonstrated that children in two Ugandan villages understood their human rights and that it was possible to involve children in decisions that affected them. It also confirmed that their perceptions of the community and welfare needs do not necessarily echo what parents, teachers and other elders think.

Our study demonstrated that Ugandan children possess good information that can inform policy and programme activities. Children's ideas should be taken seriously even when they may not be what implementers expected; community members made an effort to understand them. Our DM with children, parents, guardians and community members confirmed that it is possible for children to share their perspectives of rights in the family and community with local leaders.

All the adults in the study appreciated involving children and pledged to begin consulting children during their planning activities.

We have set the stage for other communities and development projects in Uganda to implement more child-focused policy and programming practices by involving the children in issues that affect them, in support of UNCRC Article 24 (1989).

\section{Acknowledgements}

I wish to express my gratitude to the British Institute in Eastern Africa (BIEA), which provided a grant towards fieldwork in Uganda. MaryAnn Castle, PhD reviewed and made suggestions for this article. Mr Nathan Mwesigye Byamukama, an expert on Uganda, read the first draft of this manuscript.

\section{Competing interests}

The author declares that she has no financial or personal relationship(s) that may have inappropriately influenced her in writing this article.

\section{Authors' contributions}

I designed the broader research on which this article is based as part of my PhD work. I carried out the fieldwork and collected data from children, community members and key stakeholders in Uganda. I analysed the data and I am sharing the findings through this article.

\section{References}

Acharya, L., 2010, 'Child reporters as agents of change', in B. Percy-Smith \& N. Thomas (eds.), A handbook for children and young people's participation. Perspectives from theory and practice, pp. 204-214, Routledge, London.

Archard, D., 1993, Children: Rights and childhood, Routledge, London.

Bettby, N., Strang, N.A. \& Wessells, M.G., 2006, A world turned upside down: Social ecological approaches to children in warzones, Bloomfield.

Bronfenbrenner, U., 1986, 'Ecology of the family as a context for human development: Research perspectives', Development Psychology 22, 732-42.

Casas, F., Saporiti, A., Gonzalez, M. \& Figuer, C., 2006, 'Children's rights from the point of view of children, their parents and their teachers: A comparative study between Catalonia (Spain) and II Molise (Italy)', The International Journal of Children's Rights 14, 1-75.

Chambers, R., 1997, Whose reality counts? Putting the first last, John Wiley and Sons, New York.

Chambers, R. \& Conway, G., 1991, Sustainable rural livelihoods: Practical concepts for 21st century, IDS Discussion Paper 296.

Daiute, C., 2008, 'The rights of children, the rights of nations: Developmental theory and the politics of children's rights', Journal of Social Issues 64(4), 701-723. http:// dx.doi.org/10.1111/j.1540-4560.2008.00585.x

Daily Monitor, 2014a, '300 unpaid teachers match to CAOs office', 22 June. (Mobile monitor.com).

Daily Monitor, 2014b, 'Health center halts patient admissions over falling ceiling Masindi', Bwijanga Health Centre IV, Masaka District, 23 November. (Mobile monitor.com).

Fortin, J., 2006, 'Accommodating children's rights in a post have rights act era', Modern Law Review 69(3), 299-326, [Wiley Online Library]. http://dx.doi.org/10.1111/ j.1468-2230.2006.00586.x

Freeman, M., 1983, The rights and wrongs of children, Frances Pinter, The Hague.

Freeman, M., 1997, The moral status of children: Essays on the rights of the children, Martinus Nijhoff Publishers, The Hague.

Freeman, M., 2000, 'The future of children's rights', Children and Society 14, 277-293. http://dx.doi.org/10.1111/j.1099-0860.2000.tb00183.x

Government of Uganda (GOU), 1995, The Constitution of the Republic of Uganda Government Printers, Entebbe.

Government of Uganda (GOU), 2009, Situation analysis of vulnerable children (SITAN), National Council for Children (NCC), Kampala.

Government of Uganda (GOU), 2013, Ministry of planning and economic development September, Millennium Development Goals Report for Uganda 2013, Special theme: Drives of MDG Progress in Uganda and implications for the Post 2015 Development Agenda.

Government of Uganda (GOU), 2012, 'Health and Education in Uganda', viewed 06 May 2013, from http://www.worldbank.org/en/country/uganda/publication/ uganda-service-delivery-indicators-health-education-service

Groenewald, T., 2004, 'A phenomenology research design illustrated', International Journal of Qualitative Methods 3(1), 1-25.

Gwirayi, P. \& Shumba, A., 2011, 'Children's rights: How much do Zimbabwe urban secondary school pupils know?', International Journal of Children's Rights 19(2) 195-204, viewed 10 August 2012, from ingentaconnect.com/deliver/connect $26 / 07 / 2011$

Hale, B., 2006, Fourth congress on family law and children's rights, understanding children's rights: Theory and Practice, Blackwell Publishing, Oxford.

Hanson, K. \& Nieuwenhuys, O., 2013, Reconceptualising children's rights in international development. Living Rights, Social Justice Translations, Cambridge University Press, Cambridge. 
Hart, R.A., 1992, Children's participation from tokenism to citizenship, Essay 4, Innocenti Research Center, UNICEF ICDC, Florence.

Herr, K., 2005, The action research dissertation: A guide to students and faculty, Sage, London.

Lansdown, G., 2001, Promoting children's rights in democratic decision-making, Innocenti Research Centre, UNICEF, Florence.

Lester, S., 1999, An introduction to phenomenological research, pp. 1-4, Stan Lester Developments, Taunton, viewed 23 May 2013, from www.sld.demon.co.uk/ resmethy.pdf.

MacNiff, J., 2002, Action research: Principles and practice, Routledge, London and New York.

Moosa-Mitha, M., 2005, 'A difference-centered alternative to theories of children's citizenship rights', Citizenship Studies 9(4), 369-388. http://dx.doi. org/10.1080/13621020500211354

Muzaki, S., 2011, 'Children as effective change agents: A case of school health clubs in the promotion of urban sanitation and hygiene', Paper presented at the East African Practitioners' Workshop on Pro-poor Urban Sanitation and Hygiene, LAICO Umubana Hotel, Kigali, 29-31 March.

National Council for Children (NCC), 2010, Report on the national early childhood development policy proposal, Consensus and validation workshop 17 and 18 August 2010, Grand Imperial Kampala.

Robson, C., 2002, Real world research: A resource for social scientists and practitionerresearchers, 2nd edn., Blackwell, Oxford.

Sabatier, P.A., 1986, 'Top-down and bottom-up approaches to implementation research: A critical analysis and suggested synthesis', Journal of Public Policy 6(1) 21-48. http://dx.doi.org/10.1017/S0143814X00003846

Smith, A.B., 2007, 'Children as social actors: An introduction', The Journal of Children's Rights 15, 1-4. http://dx.doi.org/10.1163/092755607X185537

Thomas, N., 2002, Children, family and the state. Decision-making and child participation, The Policy Press, Bristol.

Thomas, N., Gran, B. \& Hanson, K., 2010, 'Evaluating the children's commissioner for wales: Report of a participatory research study', International Journal of children's Rights 18, 19-52.

Uganda Bureau of Statistics (UBOS) and International Inc., 2012, Uganda demographic and health survey 2011, UBOS: Kampala and ICF International: Calverton, MD.
Uganda Local Government, 2011, Wakiso District, Nsangi sub-county five year development plan (2011-2016), prepared by the Technical Planning Committee.

UNICEF, 2003, Fact Sheet: A summary of the rights under the convention on the rights of the child, UNICEF Office of Research, New York.

UNICEF, 2009, 20 years of the UNCRC, viewed 22 May 2012, from http://www.unicef. org/rightsite

UNICEF, 2012, The state of the world's children 2012, Children in an urban world, New York.

UNICEF, 2013a, The children's society: The good childhood report 2013, viewed 13 May 2014, from www.childrenssociety.org.uk

UNICEF, 2013b, Report Card II, UNICEF Office of Research, New York.

United Nations, CRC, UN General Assembly, 1989, Adoption of the Convention on the rights of the child, New York, United Nations, viewed April 2012, from www. ohchr.org

United Nations, CRC/C/RWA/3-4, 2012, Rwanda's periodic report to the UN Committee on the Rights of the Child, viewed May 2013, from www.ohchr.org/ Documents/Country/Rwanda

United Nations, CRC/C/NIG/4, 2010, Nigeria's periodic report to the UN Committee on the Rights of the Child, viewed January 2014, from www.ohchr.org/Documents/ Country/Nigeria.

United Nations, CRC/C/15/add. 122, 2000, South Africa's report to the UN Committee on the Rights of the Child, viewed May 2012, from www.ohchr.org/Documents/ Coutries/SouthAfrica

United Nations, CRC/C/SR.1370, 2009, Special report on the UNCRC implementation, viewed April 2012, from www.ohchr.org

Wall, J., 2012, 'Can democracy represent children? Towards a politics of difference', Childhoods 19, 86-100. http://dx.doi.org/10.1177/0907568211406756

WHO, 2011, Uganda background paper, WHO, New York.

Winter, R., 1989, Learning from experience: Principles and practice in action research, Falmer Press, Lewes.

World Bank, 2013, World development indicators. Uganda demographic and health, World Bank, New York. 